\title{
THE BROCKMAN CREEK KIMBERLITE, EAST PILBARA, AUSTRALIA
}

\author{
B.A. Wyatt ${ }^{1}$, M. Mitchell ${ }^{2}$, S. R. Shee ${ }^{2}$, W. L. Griffin ${ }^{3}$, \& N. Tomlinson ${ }^{4}$, B. White ${ }^{5}$ \\ ${ }^{I}$ De Beers Canada Exploration Inc., Canada; ${ }^{2}$ De Beers Australia Exploration Limited, Australia; ${ }^{3}$ GEMOC, School of Earth \\ Sciences, Macquarie Univ., Australia; ${ }^{4}$ GeoScience Centre; De Beers; South Africa; ${ }^{5}$ Univ. Melbourne, Australia
}

\section{GEOLOGICAL SETTING AND DISCOVERY}

The Pilbara Craton was targeted by De Beers Australia Exploration Ltd. (DBAE) (formerly Stockdale Prospecting Ltd.) for diamond exploration primarily on the basis of its similarity to the Kaap Vaal Craton, South Africa (Figure 1). That is, it is a craton older than $3.0 \mathrm{Ga}$ and has been tectonically stable at least since 2.5 Ga. (Von Kranendonk et al. 2002). The Pilbara Craton also comprises the well known Nullagine alluvial diamond showing, as well as a scatter of other isolated diamonds. DBAE, in joint venture with Elazac and Haoma Mining NL commenced a regional exploration program in the east Pilbara in 1996, and in March 1998, the Brockman Creek kimberlite dyke (Figure 2) was discovered. This resulted from the follow up of eight trigger samples among the 418 reconnaissance samples collected within the spinel rich greenstone terrain. The trigger samples, located between 3 and $5 \mathrm{~km}$. downstream of the kimberlite dyke, each contained at least one kimberlitic spinel. Significantly, no garnets were found in the reconnaissance samples, although garnets were later found directly on top of the kimberlite.

The dyke also has a well defined magnetic expression (Figure 3) and is clearly identified by a $\mathrm{Mg}(\mathrm{OH}) 2$ and carbonate signature in the De Beers Airborne Multispectral Scanner data (Figure 4). The dyke is in fact annotated on the 1972 Geology map of the Marble Bar 1:250 000 sheet as a fault (Hickman \& Lipple 1978). It strikes $080 / 260$ degrees, and can be traced for about $20 \mathrm{~km}$. Although offset in places, it is continuous and varies in width from approximately $12 \mathrm{~m}$ to $1 \mathrm{~m}$. The strike of the dyke parallels other linear features, both mapped and evident in the magnetic data, and may have exploited $\mathrm{D}_{2}$ deformation (Archaean) features traversing the length of the Pilbara Block. The main dyke is associated with several, but lesser parallel and subparallel dykes.

The kimberlite intrudes the Corunna Downs granodiorite and adamellite batholith, through the Warrawoona greenstone belt, and the Mt. Edgar

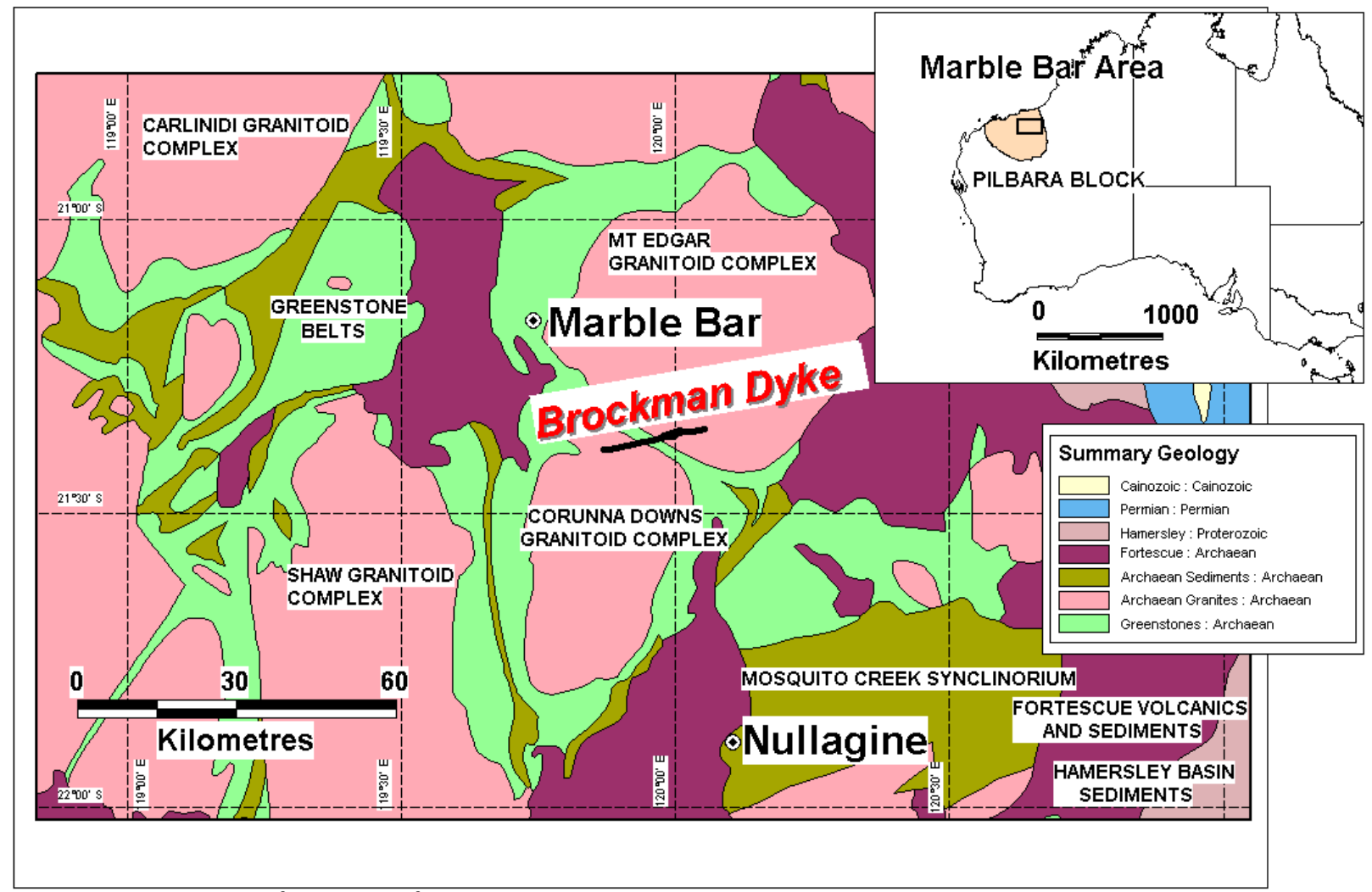

Figure 1. Location $\left(119^{\circ} 57.5^{\prime} \mathrm{E},-21^{\circ} 22.5^{\prime} \mathrm{S}\right)$ of Brockman Creek kimberlite in relation to generalised geology (after Meyers \& Hocking, 1998, Geol. Surv. of West. Aust.) showing greenstone belts, Archaean granite complexes and late Archaean cover rocks. 
foliated granodiorites and adamellites (Figure 1). The dyke was probably emplaced along pre-existing enechelon fault system. It is highly silicified in places, especially on the margins, and has been affected by carbonate alteration. The country rock shows evidence of thermal metamorphism, and/or is metasomatically affected along some contacts (Figure 2).



Figure 2: Brockman Creek Kimberlite Dyke with Warrawoona Greenstone Belt in the background. The thermally indurated country rock demarcates the outer margins of the dyke.

\section{PETROGRAPHY AND GEOCHRONOLOGY}

Petrographically, the dyke is a macrocrystic, spinel and phlogopite bearing hypabyssal facies kimberlite with globular segregationary textures. Petrographic variations across the width of the dyke and along strike suggest multiple intrusive events.

${ }^{40} \mathrm{Ar} /{ }^{39} \mathrm{Ar}$ dates obtained on two mica separates from hypabyssal facies kimberlite give an average of $1867 \pm$ $8 \mathrm{Ma}$. Two single mica grains extracted from a granite xenolith in the kimberlite give an ${ }^{40} \mathrm{Ar} /{ }^{39} \mathrm{Ar}$ age of 1809 \pm 8 Ma. (White 2000). ${ }^{87} \mathrm{Rb} /{ }^{86} \mathrm{Sr}$ geochronology on phlogopite from hypabyssal kimberlite give an isochron age of $1917 \pm 360$ Ma (op. cit). These dates are consistent with similar ages obtained for some of the Yilgarn kimberlites (White 2000; Shee et al. 1999), indicating that kimberlite events in the early to mid-
Proterozoic are not uncommon. Apatite grains extracted from the granite xenolith referred to above give a mean fission track age of $257 \pm 19$ Ma with a mean track length of $12.26 \mu \mathrm{m}$ and standard deviation of 1.93 (White 2000). If a geothermal gradient of about $18^{\circ} \mathrm{C} / \mathrm{km}$ is assumed for the past $500 \mathrm{Ma}$ (Weber et al. 2000 ), then modelling can be used to support an argument, but not prove, that about $5 \mathrm{~km}$ of denudation is possible on the Pilbara Craton during the Phanerozoic.

\section{MINERAL CHEMISTRY}

The upper mantle mineral suite associated with the Brockman kimberlite is dominated by spinels that include chromites with high $\mathrm{MgO}$ contents and diamond inclusion-type chemistries (Figure 5). The kimberlite in some places along the length of the dyke also contains peridotitic garnets with a significant subcalcic population (Figure 6). Both the sub-calcic garnet population and the high $\mathrm{MgO}$ spinels indicates that the lithosphere from which the kimberlite was derived was quite refractory in terms of its basaltic component, implying a harzburgitc composition. Ni-garnet geothermometry suggests a cool mantle geotherm at the time of intrusion of about $40 \mathrm{~mW} / \mathrm{m} 2$ (Figure 7). A significant proportion of the garnets lie within the diamond stability field. Furthermore, Y, Zr, Ti and REE relationships of the garnets suggest a highly depleted (that is, $\mathrm{MgO}$ rich) lithospheric mantle (Figures 8 and 9).

\section{DIAMONDS}

Nine small diamonds were found in the concentrates from the early exploration drilling, and subsequently 22 micro diamonds were extracted from $1710 \mathrm{~kg}$ of kimberlite. Eight mini-bulk samples comprising 196 tonnes were collected in 1999 and treated in South Africa. The results, received in 1999/2000, comprised 13 diamonds ( 0.875 carats). Thus while the kimberlite is clearly diamondiferous, it has an indicated sample grade of less than $1 \mathrm{cpht}$.

\section{DISCUSSION}

It is noteworthy that the alluvial diamonds from Nullagine some $60 \mathrm{kms}$ to the south (Fig. 1), are, based on the presence of brown spotted diamonds and stratigraphic inferences, considered to ultimately derive from Proterozoic, or perhaps Archaean kimberlites. The mineral chemistry data indicate that the kimberlite had its origins within 'cold' lithospheric mantle, and that the lithosphere had, at least geochemical, completely stabilised in Pilbara by about 2.0 Ga. The apatite fission 
track age of 257 Ma however, is substantially younger than the emplacement age, and can be used to support, but not prove, a hypothesis that significant erosion may have taken place some time during the Phanerozoic. Thus, the east Pilbara craton in spite of a stable lithosphere, may not have remained isostatically stable since cratonisation and emplacement of the Brockman Creek kimberlite.

\section{ACKNOWLEDGEMENTS}

The management from De Beers Consolidated Mines and Gary Morgan from Elazac and Haoma Mining NL are thanked for permission to present these data.

\section{REFERENCES}

Fipke C.E., Gurney J.J. \& Moore R.O. 1995, Diamond exploration techniques emphasising indicator mineral geochemistry and Canadian examples. Geol. Surv. Canada. Bull. 423.

Hickman A.H. \& Lipple S.L., 1978, Explanatory notes on the Marble Geological Sheet, Geol. Surv. West. Aust.

Gurney J.J. 1984, A correlation between garnets and diamonds in kimberlites, in, Kimberlite Occurrence and Origin: A Basis for conceptual Models in Exploration, Glover, J.E. \& Harris, P.G., eds, Geol. Dept. And Univ. Extension. Publ. 8, 143-166.
Pollack H.N \& Chapman D.S., 1977, On the regional variation of heat flow, geotherms and lithospheric thickness, Tectonophysics, 38, 279-296.

Ryan C.G., Griffin W.L. \& Pearson N. J., 1996, Garnet geotherms: pressure-temperature data from Cr-pyrope garnet xenocrysts in volcanic rocks, J. Geophys. Res., $101,5611-5625$.

Shee S.R., Vercoe S.C., Wyatt, B.A., Hwang, P.H., Campbell, A.N. \& Colgan, E.A., 1999, Discovery and geology of the Nabberu kimberlite province, Western Australia, in Proc. VII Int. Kimb. Conf., Gurney, J.J., Gurney, J.L., Pascoe, M.D., Richardson, S.H., eds, 764-772.

Sobolev N.V., Lavrent'Yev YU G., Pokhilenko N.P. \& Usova L.V. 1973, Chrome-rich garnets from the kimberlites of Yakutia and their parageneses. Dok. Akad. Nauk SSSR, 249, 1271-1220.

Van Kranendonk J.M., Hickman A.H., Smithies, R.H. \& Nelson D.R., 2002, Geology and tectonic evolution of the Archean north Pilbara terrain, Pilbara Craton, Western Australia, Economic Geology,97, 695-732.

Weber, U.D., Kohn, B.P., Nelson, D.R., and Gleadow, A.J.W., 2000, Apatite fission track thermochronology of the northern western shield, Australia, 9th international kimberlite conference on fission track dating and thermochronology: Lorne, 341-343.

White B., 2000, The geochronology and thermochronology of the Brockman Creek 01, Melita and Melita 02 kimberlites, Western Australia, Unpubl. Hons. Res. Rep., Univ. Melbourne

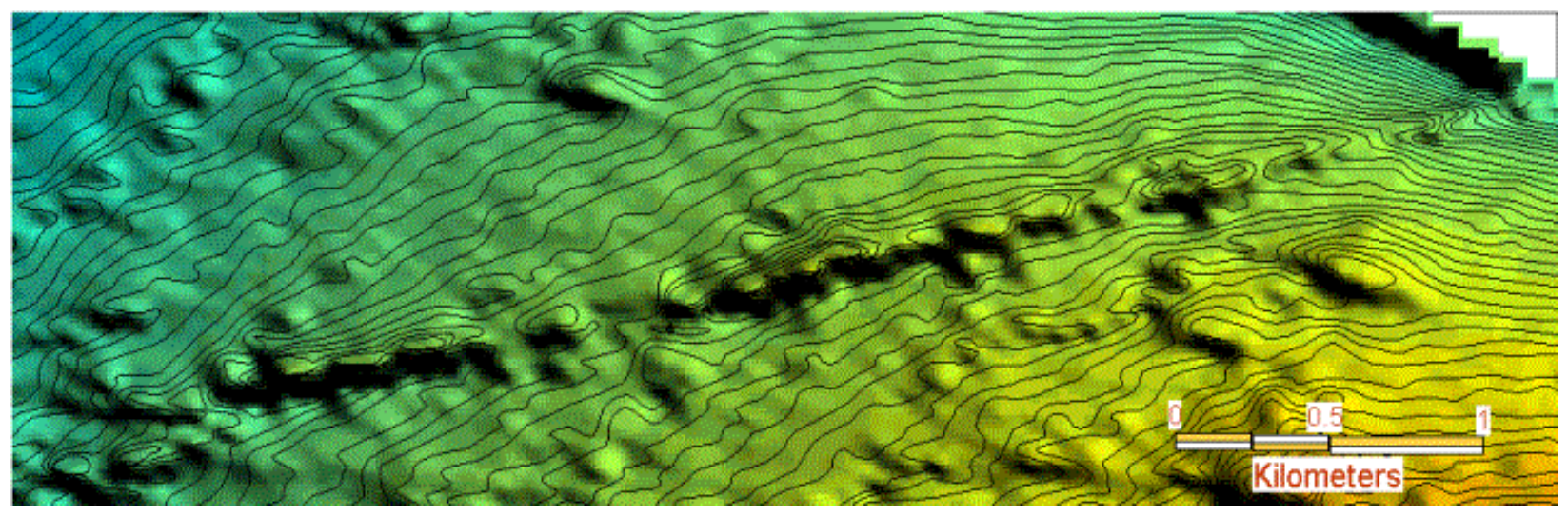

Figure 3. Detailed aeromagnetic survey over the Brockman Creek kimberlite dyke on the Corunna Down batholith. The well defined magnetic dilations along the dyke are probably an artefact of the $100 \mathrm{~m}$ line spacing. Magnetic susceptibilities range from $8 \times 10^{-5}$ SI units (highly altered) to $4817 \times 10^{-5}$ SI units (weathered sample). The country rock granite has a susceptibility of about $17 \times 10^{-5}$ SI units. Remnant magnetism is dominant with a Koenigsburger ratio of 0.9-2.1. 


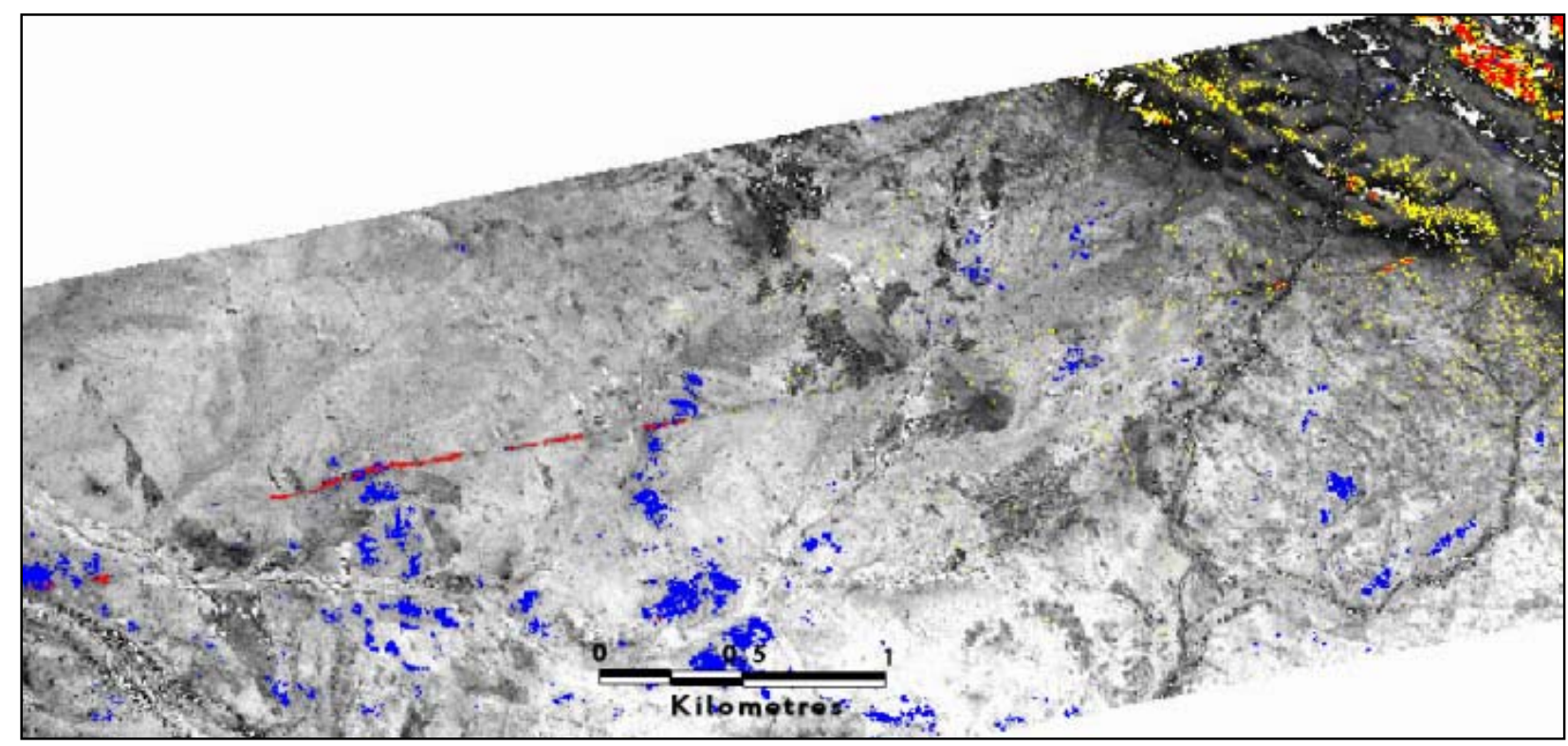

Figure 4. Airborne Multi Spectral (AMS) Scanner image over the Brockman Creek dyke southwest of the Warrawoona Greenstone Belt. A $\mathrm{Mg}(\mathrm{OH}) 2$ spectral signature is shown in red. Blue areas have carbonate signatures. Red patches in the N-E are Mg-rich mafic/ultramafics in the Warrawoona greenstone belt. Yellow areas are chlorite-rich rocks dominant in the greenstones. The dyke is cut by a stream in the southwest and the characteristic kimberlitic spectral signature has been obscured by alluvial material.

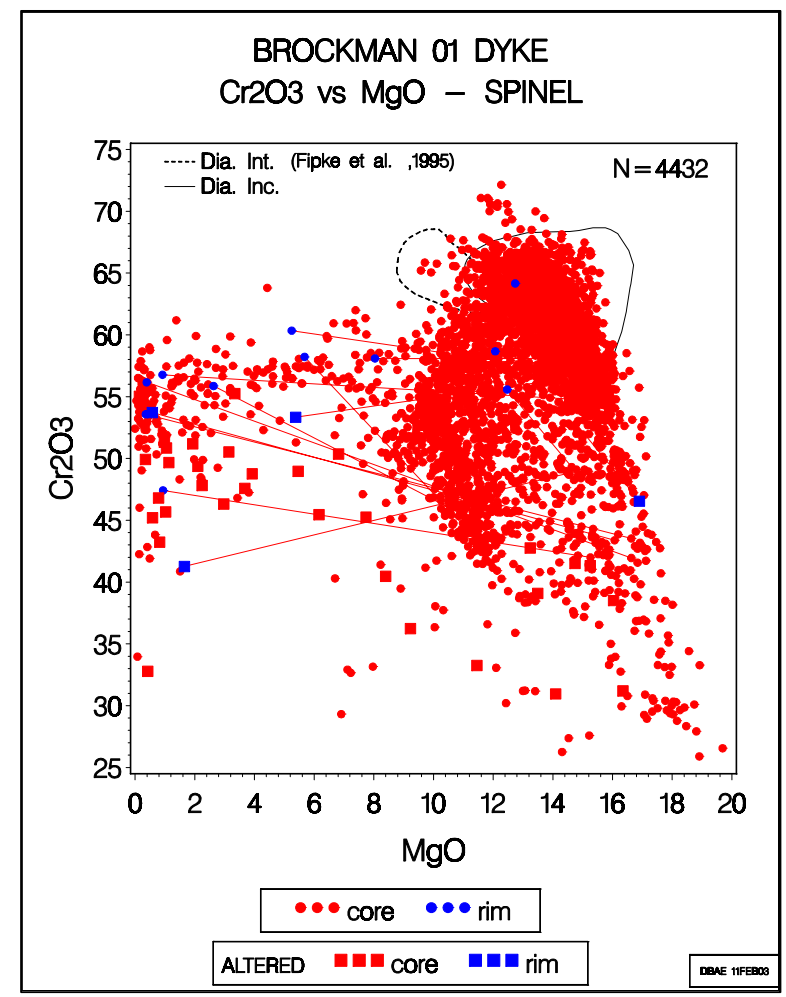

Figure 5. Note the abundance of high $\mathrm{MgO}$ and high $\mathrm{Cr}_{2} \mathrm{O}_{3}$ spinels in the diamond stability field suggesting a paragenesis within a depleted and harzburgitic mantle.

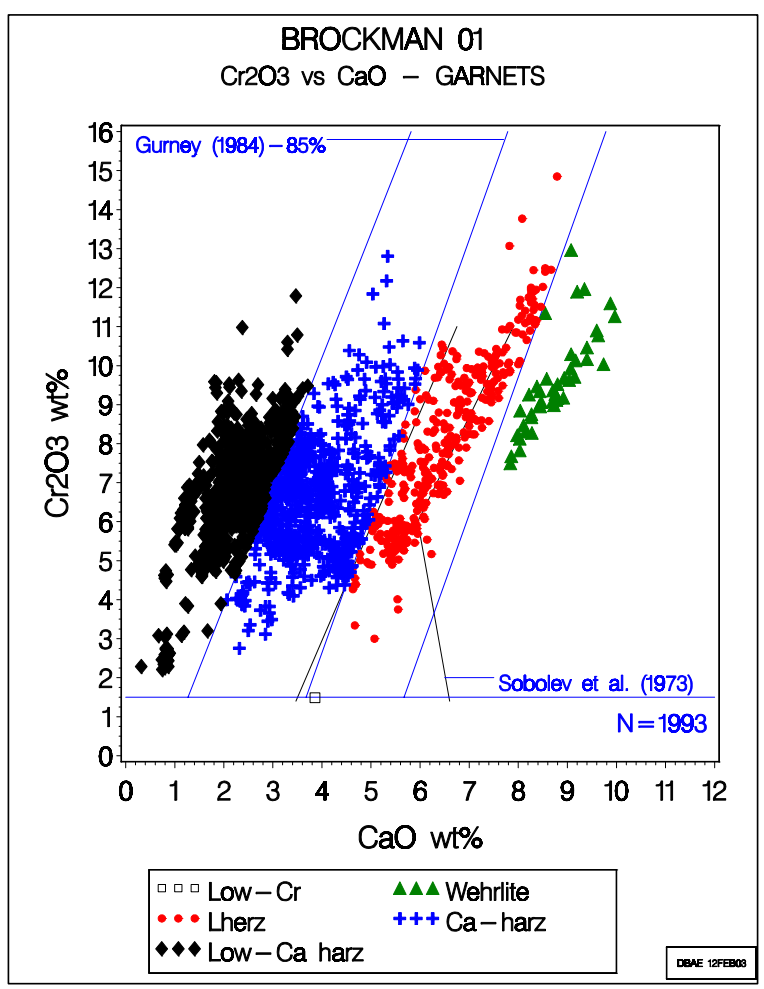

Figure 6. Similar to the spinels (Fig. 5), the abundance of sub-calcic garnets is also indicative of an origin for these garnets from a depleted and harzburgitic mantle. 


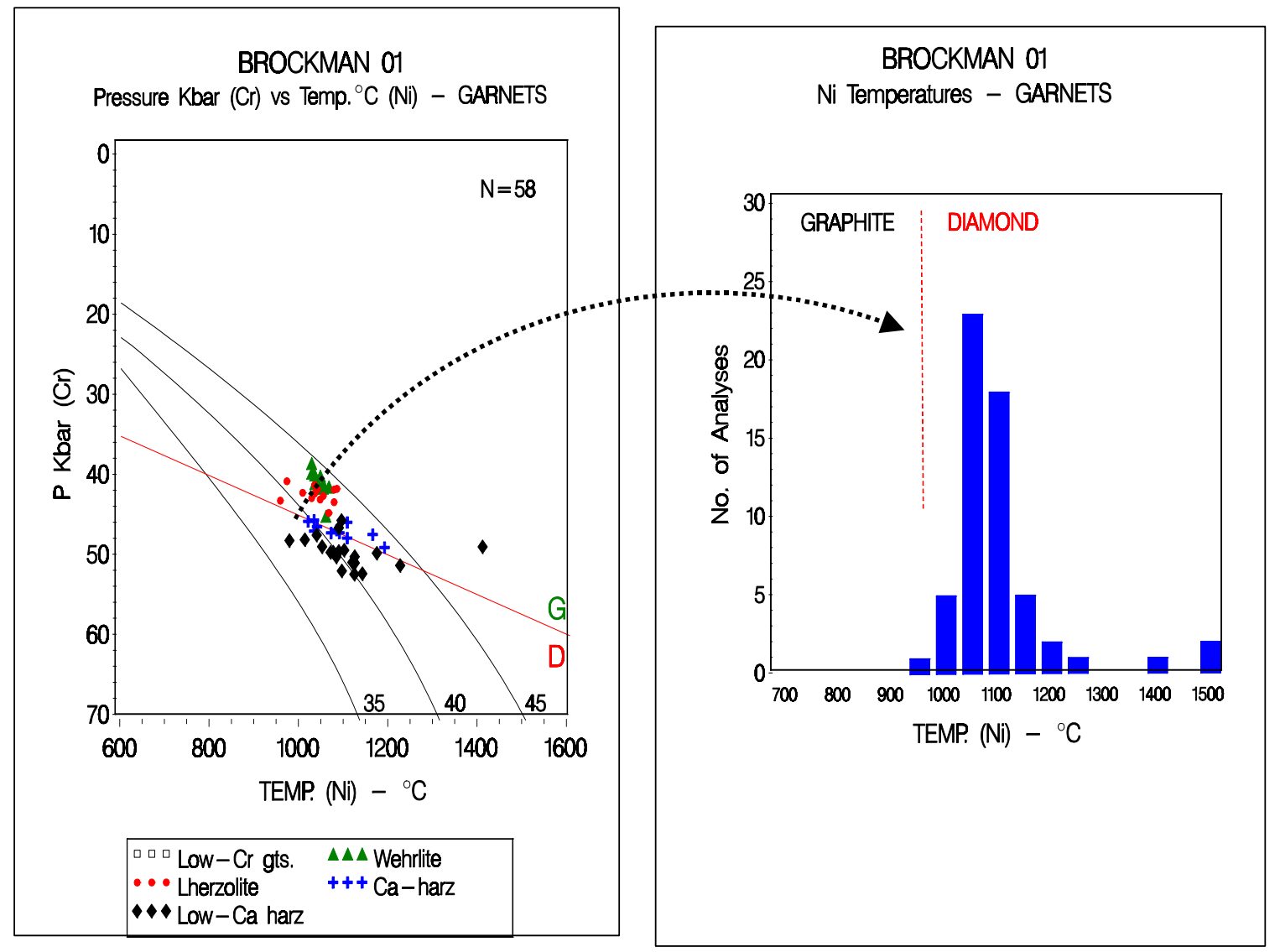

Figure 7. Temperature and pressures calculated from $\mathrm{Ni}$ and $\mathrm{Cr}$ in garnets (see Ryan et al. 1996) extracted from concentrate grains. Geotherm reference curves from Pollack and Chapman (1997). The extent of the 'diamond window' is based on the intersection of the diamond-graphite curve with the inferred geotherm for the data set and the estimated base of the lithosphere.

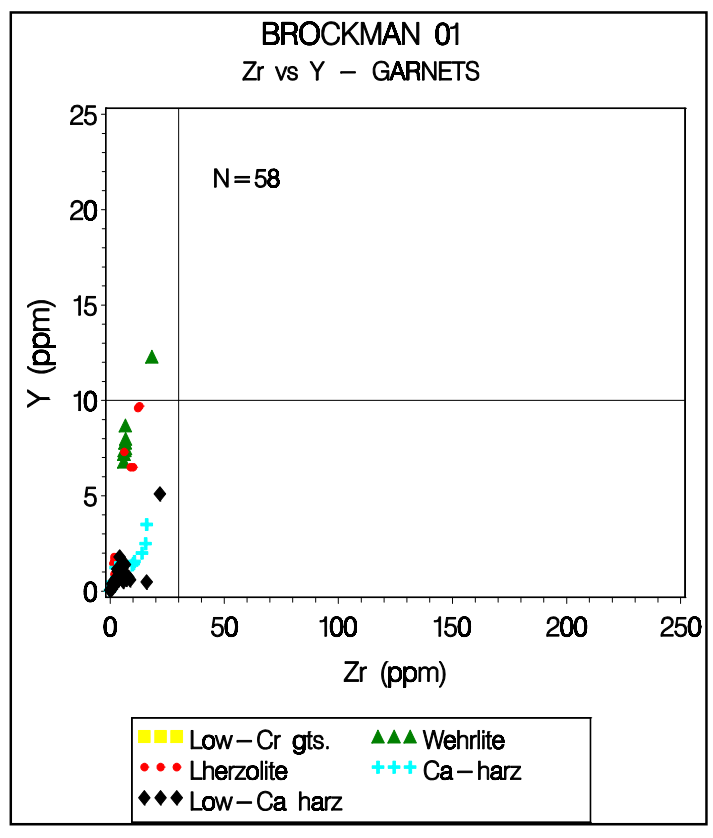

Figure 8. Y-Zr plot. Note: depleted garnets, and by implication, depleted lithosphere under Brockman Creek. Square: approx. Y-Zr values of depleted garnets.

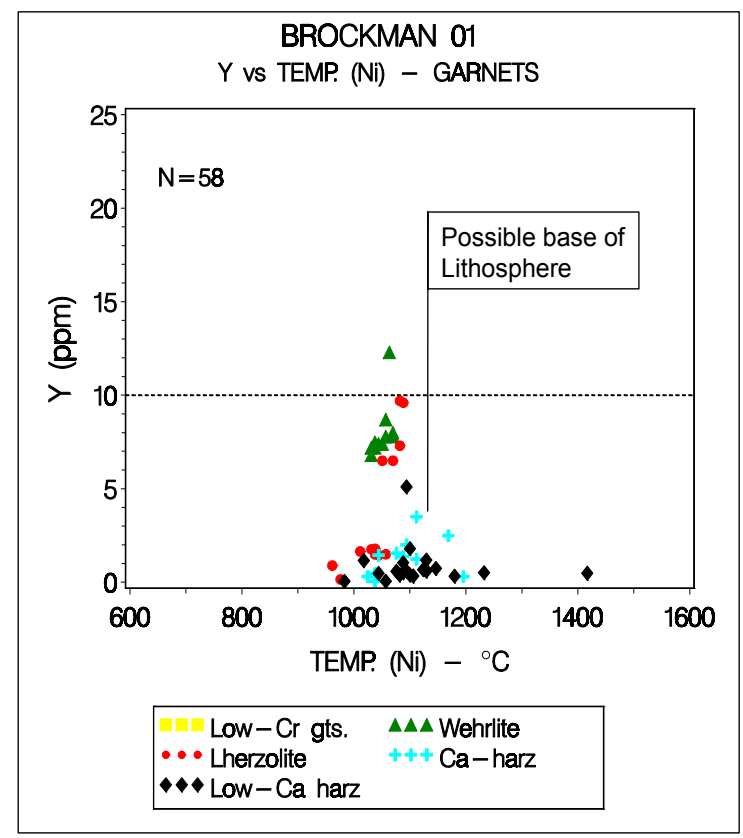

Figure 9. Y- Temp. (Ni). Plot showing possible base of lithosphere based on zone of increased $\mathrm{Y}$. 